ORIGINAL ARTICLE

\title{
Mutations in the hereditary haemochromatosis gene HFE in professional endurance athletes
}

\author{
J L Chicharro, J Hoyos, F Gómez-Gallego, J G Villa, F Bandrés, P Celaya, F Jiménez, J M Alonso, \\ A Córdova, A Lucia
}

Br J Sports Med 2004;38:418-421. doi: 10.1136/bjsm.2002.003921

See end of article for authors' affiliations .....................

Correspondence to: Dr Lucia, Department of Physiology, Universidad Europea de Madrid, Madrid, Spain; alejandro. lucia@mrfs.cisa.uem.es

Accepted 20 May 2003
Background: Hereditary haemochromatosis, a disease that affects iron metabolism, progresses with a greater or lesser tendency to induce iron overload, possibly leading to severe organ dysfunction. Most elite endurance athletes take iron supplements during their active sporting life, which could aggravate this condition.

Objective: To determine the prevalence and discuss potential clinical implications of mutations of HFE (the gene responsible for hereditary haemochromatosis) in endurance athletes.

Methods: Basal concentrations of iron, ferritin, and transferrin and transferrin saturation were determined in the period before competition in 65 highly trained athletes. Possible mutations in the HFE gene were evaluated in each subject by extracting genomic DNA from peripheral blood. The restriction enzymes SnaBl and Bcll were used to detect the mutations 845G $\rightarrow$ A (C282Y) and 187C $\rightarrow G(H 63 D)$.

Results: Our findings indicate a high prevalence of HFE gene mutations in this population (49.2\%) compared with sedentary controls (33.5\%). No association was detected in the athletes between mutations and blood iron markers.

Conclusions: The findings support the need to assess regularly iron stores in elite endurance athletes.
$\mathrm{H}$ ereditary haemochromatosis is an autosomal recessive disease in which the body's iron stores are increased, with serious negative effects on the function of several organs (liver cirrhosis, diabetes mellitus, heart failure). ${ }^{1-3}$ The clinical consequences of iron overload in these patients can be prevented by early diagnosis and appropriate treatment. ${ }^{4}$

The HFE gene plays a major role in hereditary haemochromatosis. It occurs in the short arm of chromosome $6 .{ }^{6}$ Most patients with manifest hereditary haemochromatosis are homozygous for the $\mathrm{C} 282 \mathrm{Y}$ mutation, and a small proportion are heterozygous for both the $\mathrm{C} 282 \mathrm{Y}$ and H63D mutation of the HFE gene. ${ }^{7}$ Only a few affected cases show C282Y heterozygosity or H63D homozygosity. Subjects with these two genotypes generally display fewer markers of iron overload than $\mathrm{C} 282 \mathrm{Y}$ homozygotes. ${ }^{8}$ Although these patients have a very low or no risk of developing cirrhosis or other complications, some authors suggest that they should be treated similarly to $\mathrm{C} 282 \mathrm{Y}$ homozygotes. ${ }^{9}$ Moreover, despite the compound $\mathrm{C} 282 \mathrm{Y} / \mathrm{H} 63 \mathrm{D}$ heterozygous defect expressing the disease with low penetrance $(0.44-1.5 \%),{ }^{6}{ }^{10}{ }^{11}$ it has been identified as an independent risk factor of death from cardiovascular causes or myocardial infarction. ${ }^{12}{ }^{13}$

There is considerable evidence to suggest that mutations in the HFE gene, even H63D heterozygosity, affect blood iron indices, and subjects with one or more mutations show higher blood iron concentrations and transferrin saturation than subjects without mutations. ${ }^{14}$ Deugnier et al ${ }^{15}$ recently explored factors that induce the increased iron reserves observed in elite cyclists, and suggested that increased serum ferritin was mainly related to the excessive iron supplements taken by these athletes rather than to mutations in the HFE gene (C282Y and H63D).

Despite the tremendous advances made in the area of genetic mutations in disease since $1996,{ }^{6}{ }^{16}$ genetic evaluations such as screening the general population are not recommended. ${ }^{17}$ Phenotypic analysis based on transferrin saturation still seems to be the best and most economical diagnostic method to either preclude or warrant a more in depth analysis of the disease in a particular subject. ${ }^{18}{ }^{19}$ Thus, if transferrin saturation is $>45 \%$, a genetic analysis of HFE mutations and serum ferritin determination would be called for, to better estimate the subject's iron stores.

This study was designed to evaluate the prevalence of HFE mutations in elite endurance athletes. The results were compared with those of a control group matched by region of origin.

\section{MATERIALS AND METHODS}

Subjects

Sixty five elite, male athletes ( 50 professional road cyclists and 15 Olympic class endurance runners) from Spain were enrolled in the study. Written consent was obtained from each subject according to the guidelines of the Universidad Complutense, Madrid.

The mean (SD) age, height, mass, and maximum oxygen consumption ( $\left.\mathrm{VO}_{2} \mathrm{MAX}\right)$ of the athletes were: 26 (3) years, 178 (5) $\mathrm{cm}, 66.7$ (6.1) kg, and 71.8 (7) $\mathrm{ml} / \mathrm{kg} / \mathrm{min}$ respectively. The subjects were previously confirmed to be healthy by a medical examination including electrocardiography and cardiac ultrasonography. No subject had a familial or personal history of endocrine or metabolic disease. No exogenous substances had ever been detected in anti-doping checks performed in the subjects by the corresponding official organisations. Most $(90 \%)$ of the athletes took iron supplements (not including the C282Y/H63D heterozygous subject (see the Results section)) at a mean dose of $105 \mathrm{mg}$ Fe on alternate days for at least six months of the year. Doses and treatment regimens were similar in each subject.

A control group $(n=134)$ composed of random sedentary men from Spain also entered the study.

Measurement of blood iron markers in the athletes Fasting blood samples were collected from all the athletes after at least three rest days during the period before competition. When available, serum ferritin concentrations 
(determined 12 and 6 months before the study) were recorded.

Serum iron concentrations were measured using a standard colorimetric method (Roche/Hitachi 714; Roche Diagnostics Corporation, Indianapolis, Indiana, USA). Transferrin concentration was determined by rate immunoturbidimetry (OSAX anti-serum for the Behring nephelometer; Dade Behring Marburg GmbH, Marburg, Germany). Serum transferrin saturation was calculated from these data as follows:

Transferrin saturation $(\%)=($ serum iron concentration $(\mathrm{mol} / \mathrm{l}) /(2 \times$ transferrin concentration $(\mathrm{mol} / \mathrm{l}))) \times 100$.

Serum ferritin concentrations were measured by chemiluminescence immunoassay (N-latex ferritin kit; Dade Behring Marburg $\mathrm{GmbH}$ ). The coefficients of interassay and intraassay variability averaged $1.2 \%$ and $1.8 \%$ for serum iron, $2.3 \%$ and $2.7 \%$ for transferrin concentration, and $1.2-3.1 \%$ and $1.0-4.6 \%$ for serum ferritin.

Serum ranges considered normal were 13-32 $\mu \mathrm{mol} / \mathrm{l}$ for iron, $24-336 \mathrm{~g} / \mathrm{l}$ for transferrin, $24-45 \%$ for transferrin saturation, and 20-300 $\mu \mathrm{g} / \mathrm{l}$ for ferritin. ${ }^{18}$

\section{Study of C282Y and H63D mutations in all subjects}

Genomic DNA was extracted from peripheral blood using a standard phenol/chloroform procedure followed by alcohol precipitation. DNA amplification was performed using polymerase chain reaction (PCR) with specific primers for the two HFE gene mutations as described previously. ${ }^{10}$ The PCR conditions for both mutations were as follows: initial denaturation at $95^{\circ} \mathrm{C}$ for five minutes; 35 cycles at $95^{\circ} \mathrm{C}$ for one minute, $55^{\circ} \mathrm{C}$ for 45 seconds, $72^{\circ} \mathrm{C}$ for one minute, and a final extension at $72^{\circ} \mathrm{C}$ for five minutes. The PCR products were then subjected to enzymic digestion for two hours, with restriction endonucleases cleaving the DNA at specific points such that the presence or absence of the mutations could be detected. The restriction enzymes used were SnaBI for the $845 \mathrm{G} \rightarrow \mathrm{A}(\mathrm{C} 282 \mathrm{Y})$ mutation and BclI for the $187 \mathrm{C} \rightarrow \mathrm{G}(\mathrm{H} 63 \mathrm{D})$ mutation. The digested fragments were visualised by electrophoresis on $2 \%$ agarose gels stained with ethidium bromide (fig 1).

\section{Statistical analysis}

All variables were tested for normality. We compared the distribution of HFE genotypes in both athlete and control

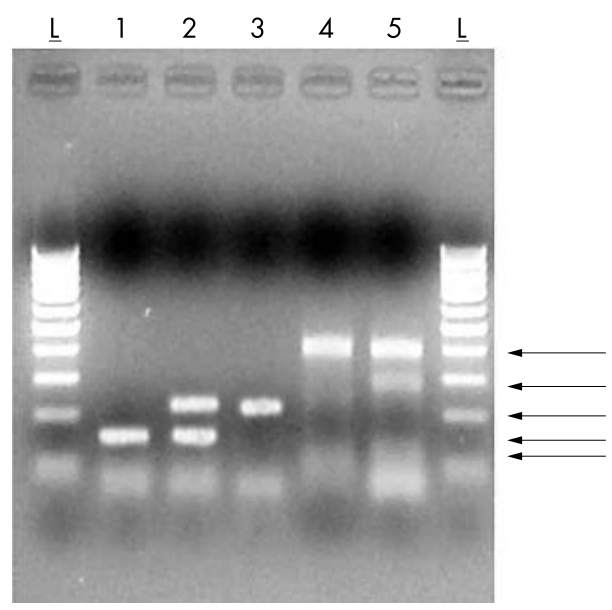

Figure 1 Agarose gel (2\%) stained with ethidium bromide. Arrows (from top to bottom) indicate the fragments generated after digestion with Bcll and SnaBI: 420, 300, 220, 160, and $120 \mathrm{pb}$. The samples applied were: lane L, molecular mass markers (ladder 100); lane 1 , H63D (-/-); lane 2, H63D (-/+); lane 3, H63D (+/+); lane 4, C282Y $(-/-)$; lane 5, C282Y (-/+). groups with the Fisher exact test. Ferritin data for athletes were $\log$ transformed to normalise the distribution before analysis. Differences between genotypes in the athlete group were identified by one way analysis of variance. In this group, the paired $t$ test was used to compare the variables according to the presence or lack of mutations. Correlation between paired quantitative data was assessed by the Spearman test. All statistical analyses were performed using SPSS 9.0 software for Windows. The level of significance was set at 0.05 .

\section{RESULTS}

Table 1 shows the prevalence of the different HFE gene mutations in the two groups. The proportion of subjects without a HFE gene mutation was significantly higher in the control group than in the athlete group $(66.5 \% \vee 50.8 \%$; $\mathrm{p}=$ 0.03 ). H63D heterozygosity occurred in $41.5 \%$ of the athletes and $24.6 \%$ of the controls $(p=0.01$ ). No other significant difference was found between groups. No homozygote for the C282Y mutation was detected in athletes or controls.

Table 2 shows biometric variables, maximum aerobic capacity, and blood iron markers in subgroups of athletes established according to the type of HFE mutation carried. No significant differences in any of the variables $(p>0.05)$ were detected among subgroups.

The different variables were also compared in the athlete group in terms of the presence or absence of mutations (table 3). No differences were observed among the subgroups.

\section{DISCUSSION}

The most important finding of our study was the high proportion of endurance athletes with a mutation in the HFE gene (49.2\%), 29 (44.6\%) of whom carried an H63D mutation and three $(4.6 \%)$ a C282Y mutation. The prevalence of H63D heterozygosity was significantly higher $(\mathrm{p}=0.01)$ than in controls $(41.5 \% \vee 24.6 \%)$. Our results are in agreement with those of previous research showing that in the general population of Spain the prevalence of the H63D mutation ranges from $16 \%{ }^{20}$ to $30.4 \%,{ }^{21}$ and $\mathrm{C} 282 \mathrm{Y}$ mutations occur in $2 \%^{20}$ to $4.4 \%$ depending in both cases on the geographical region. ${ }^{22}$

Thus, the prevalence observed here (especially for H63D) is much higher than that previously reported in non-athletic subjects, yet is similar to rates recently observed by Deugnier et al, ${ }^{15}$ who also warned of a higher prevalence of H63D mutations in French cyclists compared with healthy controls. ${ }^{15}$ It remains to be seen if these mutations afford any metabolic advantage to these athletes during exertion. We detected no significant differences in $\mathrm{VO}_{2} \mathrm{MAX}$ between subjects with or without the mutation, thus we cannot confirm this hypothesis.

Although there appeared to be no relation in the athlete group between the presence and absence of mutation with respect to the blood iron markers, it is observed that $61.1 \%$ of

Table 1 Percentage distribution of HFE genotypes in elite endurance athletes and sedentary controls

\begin{tabular}{llll}
\hline Genotype & Athletes $(\mathbf{n}=65)$ & Controls $(\mathbf{n}=134)$ & $\mathbf{p}$ Value \\
\hline wt/wt & 50.8 & 66.5 & 0.03 \\
C282Y/wt & 3.1 & 4.5 & $\mathrm{NS}$ \\
$\mathrm{H} 63 \mathrm{D} / \mathrm{wt}$ & 41.5 & 24.6 & 0.01 \\
$\mathrm{C} 282 \mathrm{H} / \mathrm{H} 63 \mathrm{D}$ & 1.5 & 0.7 & $\mathrm{NS}$ \\
$\mathrm{H} 63 \mathrm{D} / \mathrm{H} 63 \mathrm{D}$ & 3.1 & 3.7 & $\mathrm{NS}$ \\
\hline
\end{tabular}

wt/wt, Wild-types; C282Y/wt, heterozygotes for the C282Y mutation; $\mathrm{H} 63 \mathrm{D} / \mathrm{wt}$, heretozygotes for the H63D mutation; C282Y/H63D, compound heterozygotes; H63D/H63D, homozygotes for the H63D mutation; NS, not significant. 
Table 2 Biometric variables, maximum aerobic capacity, and blood iron markers in athletes $(n=65)$ grouped by HFE genotypes

\begin{tabular}{|c|c|c|c|c|c|c|}
\hline & $w t / w t$ & $\mathrm{C} 282 \mathrm{Y} / \mathrm{wt}$ & $\mathrm{H} 63 \mathrm{D} / \mathrm{wt}$ & C282Y/H63D & H63D/H63D & $\begin{array}{l}\text { Normal } \\
\text { ranges }\end{array}$ \\
\hline Number & 33 & 2 & 27 & 1 & 2 & \\
\hline Age (years) & $26(3)$ & $28(2)$ & $26(4)$ & 27 & 27 (1) & \\
\hline Height $(\mathrm{cm})$ & $178(6)$ & $175(2)$ & $178(6)$ & 183 & $172(3)$ & \\
\hline Mass $(\mathrm{kg})$ & $67.4(5.2)$ & $61.0(0.5)$ & $67.1(6.6)$ & 70 & $55.5(2.1)$ & \\
\hline $\begin{array}{l}\mathrm{VO}_{2} \mathrm{MAX} \\
(\mathrm{ml} / \mathrm{kg} / \mathrm{min})\end{array}$ & 70.8 (6.8) & $75.6(0.9)$ & $72.3(6.6)$ & 81.2 & & \\
\hline $\begin{array}{l}(\mathrm{ml} / \mathrm{kg} / \mathrm{min}) \\
\mathrm{Fe}(\mu \mathrm{mol} / \mathrm{l})\end{array}$ & $19.3(5.7)$ & $14.1(0.3)$ & $19.0(6.4)$ & 22.2 & $19.9(9.9)$ & \\
\hline Ferritin ( $\mu \mathrm{g} / \mathrm{l})$ & 224.7 (153.2) & 210.0 (141.4) & 252.4 (148.9) & 374 & $471.0(80.6)$ & $20-300$ \\
\hline Transferrin (g/l) & $232.4(26.8)$ & 174.0 & $224.4(23.8)$ & 174.5 & & $24-336$ \\
\hline TSI (\%) & $35.8(8.0)$ & 35.1 & $35.1(12.1)$ & 55.9 & & $24-45$ \\
\hline
\end{tabular}

Values are mean (SD). No significant differences in any of the variables $(p>0.05)$ were detected among the athlete subgroups.

wt/wt, Wild-types; $\mathrm{C} 282 \mathrm{Y} / \mathrm{wt}$, heterozygotes for the $\mathrm{C} 282 \mathrm{Y}$ mutation; $\mathrm{H} 63 \mathrm{D} / \mathrm{wt}$, heretozygotes for the H63D mutation; C282Y/H63D, compound heterozygotes; H63D/H63D, homozygotes for the H63D mutation; $\mathrm{VO}_{2} \mathrm{MAX}$ maximum aerobic capacity; Fe, iron; TSI, transferrin saturation index.

Table 3 Comparison of variables according to the presence or absence of HFE gene mutations

\begin{tabular}{lllllllll}
\hline & $\begin{array}{l}\text { Age } \\
\text { (years) }\end{array}$ & $\begin{array}{l}\text { Height } \\
(\mathbf{c m})\end{array}$ & $\begin{array}{l}\text { Mass } \\
(\mathbf{k g})\end{array}$ & $\begin{array}{l}\mathrm{Vo}_{2} \mathrm{MAx} \\
(\mathbf{m l} / \mathbf{k g} / \mathbf{m i n})\end{array}$ & $\mathrm{Fe}(\mu \mathrm{mol} / \mathbf{l})$ & Ferritin $(\boldsymbol{\mu g} / \mathbf{l})$ & Transferrin $(\mathbf{g} / \mathbf{l})$ & TSI (\%) \\
\hline HFE mutation & $26(3)$ & $178(6)$ & $66.1(6.9)$ & $72.8(6.5)$ & $18.8(6.3)$ & $267.2(151.3)$ & $218.8(27.6)$ & $36.2(12.4)$ \\
No HFE mutation & $26(3)$ & $178(6)$ & $67.4(5.2)$ & $70.8(6.8)$ & $19.3(5.7)$ & $224.7(153.2)$ & $232.4(26.8)$ & $36.1(10.8)$ \\
Normal ranges & & & & & $13-32$ & $20-300$ & $24-336$ & $24-45$ \\
\hline
\end{tabular}

Values are mean (SD). No significant differences in any of the variables $(p>0.05)$ were detected among the athlete subgroups.

Fe, Iron; TSI, transferrin saturation index.

\section{Take home message}

The prevalence of mutations in the HFE gene (responsible for hereditary haemochromatosis, a disease in which the body's iron stores are increased) seems to be high among elite endurance athletes (about $49 \%$ ). As most elite endurance athletes take iron supplements, regular assessment of their iron reserves is recommended to prevent iatrogenic iron overload.

athletes with high ferritin concentrations had a mutated HFE gene. It is known that long term exposure to small amounts of iron can lead to atherogenesis and ischaemia/reperfusion damage caused by free radical formation. ${ }^{23}$ Even minimally increased iron deposits in people heterozygous for the mutations could be detrimental and enhance the risk of cardiovascular disease. ${ }^{24}$ Thus, taken together, our findings and those of Deugnier et al ${ }^{15}$ suggest the need to regularly assess iron status-that is, ferritin concentrations and transferrin saturation-in elite endurance athletes to prevent iatrogenic iron overload in this population.

In conclusion, the prevalence of HFE gene mutations is high among elite endurance athletes (runners and professional cyclists). Regular determination of their iron stores is thus recommended.

\section{ACKNOWLEDGEMENTS}

We thank Ana Burton for translation of the manuscript.

\section{Authors' affiliations}

J L Chicharro, Departamento de Enfermería, Universidad Complutense, Madrid, Spain

J Hoyos, Asociación Deportiva Banesto, Madrid
F Gómez-Gallego, F Bandrés, Laboratorio de Biopatología,

Departamento de Toxicología y Legislación Sanitaria, Universidad Complutense

J G Villa, INEF de Castilla y León, Universidad de León, León, Spain

P Celaya, Grupo Deportivo ONCE, Spain

F Jiménez, Universidad de Castilla-La Mancha, Spain

J M Alonso, Servicios Médicos RFEA, Madrid

A Córdova, Departamento de Fisiología, Universidad de Valladolid, Spain

A Lucia, Department of Physiology, Universidad Europea de Madrid, Madrid

\section{REFERENCES}

1 Andrews NC, Levy JE. Iron is hot: an update on the pathophysiology of hemochromatosis. Blood 1998;92:1845-51.

2 Bothwell TH, MacPhail AP. Hereditary hemochromatosis: etiologic, pathologic, and clinical aspects. Semin Hematol 1998;35:55-71.

3 Nichols GM, Bacon BR. Hereditary hemochromatosis: pathogenesis and clinical features of a common disease. Am J Gastroenterol 1989:84:851-62.

4 Powell LW, Jazwinska E, Halliday JW. Primary iron overload. In: Brock JH, Halliday JW, Pippard MJ, et al. Iron metabolism in health and disease. London: Saunders, 1994:227-70.

5 Vaquer $\mathbf{P}$, Muncunill J, Forteza A, et al. Utilidad de la eritroferesis mecánica en la hemocromatosis hereditaria. Resultados preliminares [abstract]. Gastroenterol Hepatol 1999;22:35.

6 Feder JN, Gnirke A, Thomas W, et al. A novel MHC class I-like gene is mutated in patients with hereditary haemochromatosis. Nat Genet 1996:13:399-408.

7 Crawford DH, Jazwinska EC, Cullen LM, et al. Expression of HLA-linked haemochromatosis in subjects homozygous or heterozygous for the C282Y mutation. Gastroenterology 1998;114:1003-8

8 Basseft ML. Haemochromatosis: iron still matters. Intern Med J 2001:31:237-42.

9 Adams PC, Kertesz AE, McLaren CE, et al. Population screening for hemochromatosis: a comparison of unbound iron-binding capacity, transferrin saturation, and C282Y genotyping in 5,211 voluntary blood donors. Hepatology 2000;31:1160-4.

10 Beutler E, Gelbart T, West C, et al. Mutation analysis in hereditary hemochromatosis. Blood Cells Mol Dis 1996;22:187-94.

11 Jouanolle AM, Gandon G, Jezequel P, et al. Haemochromatosis and HLA-H. Nat Genet 1996;14:251-2.

12 Roest M, van der Schouw YT, de Valk B, et al. Heterozygosity for a hereditary hemochromatosis gene is associated with cardiovascular death in women. Circulation 1999; 100:1268-73. 
13 Tuomainen TP, Kontula K, Nyyssonen K, et al. Hemochromatosis gene HFE Increased risk at acute myocardial infarction in carriers of the hemochromatosis gene Cys282Tyr mutation: a prospective cohort study in men of eastern Finland. Circulation 1999;100:1274-9.

14 Burt MJ, George PM, Upton JD, et al. The significance of haemochromatosis gene mutations in the general population: implications for screening. Gut 1998;43:830-6.

15 Deugnier $Y$, Loréal $O$, Carré $F$, et al. Increased body iron stores in elite road cyclists. Med Sci Sports Exerc 2002;34:876-80.

16 Brissot P, Moirand R, Gudayer D, et al. Hemochromatosis after the gene discovery: revisiting the diagnostic strategy. J Hepatol 1998;28:14-8

17 Davis JG. Population screening for hemochromatosis: the evolving role of genetic analysis. Ann Intern Med 1998;129:905-8.

18 Martínez-Vázquez C, Martínez Cadilla J, Gil M, et al. Prevalence of hereditary hemochromatosis among healthy workers. Diagnostic value of transferrin saturation assay. An Med Interna 2000;17:628-31.
19 McDonnell SM, Phatak PD, Felitti V et al. Screening for hemochromatosis in primary care settings. Ann Intern Med 1998;129:962-70.

20 Alvarez S, Mesa MS, Bandrés F, Arroyo E. C282Y and H63D mutation frequencies in a population from central Spain. Dis Markers 2001;17:111-14.

21 Merryweather-Clarke AT, Pointon JJ, Shearman JD, et al. Global prevalence of putative haemochromatosis mutations. J Med Genet 1997;34:275-8.

22 Fábrega E, Castro B, Sánchez-Castro L, et al. The prevalence of the Cys282Tyr mutation in the hemochromatosis gene in Cantabria in patients diagnosed with hereditary hemochromatosis. Med Clin (Barc) 1999; 112:451-3.

23 de Valk B, Marx JJ. Iron, atherosclerosis and ischemic heart disease. Arch Intern Med 1999; 159:1542-8

24 de Valk B, Witlox RSGM, van der Schouw YT, et al. Biochemical expression of heterozygous hereditary hemochromatosis. Eur J Intern Med 2000;11:317-21.

\section{ELECTRONIC PAGES}

\section{BJSM Online case reports: http://bjsm.bmijournals.com/}

7

he following electronic only articles are published in conjunction with this issue of BJSM.

\section{Upper airway obstruction masquerading as exercise induced bronchospasm in an elite road cyclist \\ K E Fallon}

This case concerns an elite road cyclist who complained of occasional dyspnoea and inspiratory difficulty during intense exercise. Clinical examination was normal and the final diagnosis was vocal cord dysfunction, a paradoxical closure of the vocal cords during inspiration which is highly associated with inspiratory stridor at high rates of ventilation. Awareness by the sports physician of this not uncommon condition is important to avoid misdiagnosis.

(Br J Sports Med 2004;38:e9) http://bjsm.bmjjournals.com/ cgi/content/full/38/4/e9

\section{Cardiovascular stress on an elite basketball referee during neonatal competition \\ A S Leicht}

This case report examined the cardiovascular stress imposed on an experienced elite basketball referee during national competition. The average heart rate was similar for all matches, approximated $73 \%$ of maximum heart rate, and was experienced for most $(>63 \%)$ of the match. Similar relative exercise intensity was demonstrated regardless of match play (men's $v$ women's) and officiating type (two $v$ three-referee). Further study is needed to document the physiological characteristics of elite basketball referees for greater performance.

(Br J Sports Med 2004;38:e10) http://bjsm.bmjjournals.com/ cgi/content/full/38/4/e10

\section{An unusual presentation of immersion foot \\ D M Macgregor}

We report a case of "green foot" in a child with a plaster cast applied for a fractured metatarsal who subsequently represented with circulatory compromise. The foot was green and smelly and profuse Pseudomonas aeruginosa was cultured. The infection cleared with simple exposure to air. Perhaps this diagnosis should be considered in patients presenting with circulatory compromise in a cast as severe infection can result in amputation.

(Br J Sports Med 2004;38:el1) http://bjsm.bmjjournals.com/ cgi/content/full/38/4/el l 


\section{PostScript}

\section{LETTER}

If you have a burning desire to respond to a paper published in Br J Sports Med, why not make use of our "rapid response" option?

Log on to our website (www.bjsportmed. com), find the paper that interests you, click on "full text" and send your response by email by clicking on "eletters" submit a response.

Providing it isn't libellous or obscene, it will be posted within seven days. You can retrieve it by clicking on "read eletters" on our homepage.

\section{Sodium ingestion and the prevention of hyponatraemia during exercise}

The study of Twerenbold et $a l^{1}$ is important for a number of reasons, not all of which may have been emphasised sufficiently by the authors.

Firstly, it confirms that a rate of fluid intake of $1000 \mathrm{ml} / \mathrm{h}$ is too high for a group of female runners running at $\sim 10 \mathrm{~km} / \mathrm{h}$ and who would therefore complete a $42 \mathrm{~km}$ marathon in about 4.25 hours. As the athletes drank 4 litres and gained $2 \mathrm{~kg}$ during the trial, their average rate of weight loss (as opposed to sweat rate) was about $500 \mathrm{ml} / \mathrm{h}$. As not all of the weight lost during exercise is sweat and as much as $1-3 \mathrm{~kg}$ of this weight loss may result from fuel and water losses that do not contribute to dehydration, ${ }^{23}$ the absolute maximum rate at which these athletes should have ingested fluid during exercise was probably even less than $500 \mathrm{ml} / \mathrm{h}$. This is substantially less than the drinking guidelines of the American College of Sports Medicine $^{45}$ and the Gatorade Sports Science Institute, ${ }^{6}$ which have promoted rates of fluid ingestion of up to $1200-1800 \mathrm{ml} / \mathrm{h}$. As there is no evidence that gaining weight during exercise improves performance ${ }^{78}$ whereas there is good evidence that athletes who either lose no weight or who gain weight during exercise are increasingly likely to $(a)$ have an impaired performance, ${ }^{7}(b)$ develop troubling gastrointestinal symptoms, ${ }^{7-10}$ or $(c)$ finish the race with serum sodium concentrations below about $128 \mathrm{mmol} / \mathrm{l}$ causing hyponatraemic encephalopathy, ${ }^{11-13}$ it is not immediately clear why the authors chose such high rates of fluid intake in these athletes. Except, perhaps, if they wished to "prove" the value of sodium ingestion during exercise. I note, for example, that the study was funded by a commercial company that, I am informed, markets a sports drink containing sodium chloride.

For it seems highly probable that if athletes overdrink so that they retain fluid and gain weight, then the extent to which their serum sodium concentration falls will be influenced, albeit to a quite limited extent, by the sodium content of the ingested fluids. This indeed was shown by the results of this study. But whether that finding has relevance to the sodium requirements of athletes who are specifically advised not to overdrink during exercise to ensure that they do not develop hyponatraemic encephalopathy ${ }^{13}$ is an entirely different question, which cannot be answered with the study design chosen by these authors.

For example, the presence of a control group who drank according to the dictates of thirst ("ad libitum") and not according to the guidelines of influential sports medical ${ }^{45}$ and

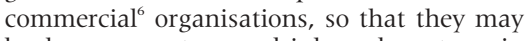
be less prone to overdrink and so to gain weight during exercise, would have established that athletes who lose more than 1-3 kg during exercise do not develop symptomatic hyponatraemic encephalopathy ${ }^{11-16}$ even though they are both dehydrated and sodium deficient. Rather, they are more likely to finish such races with raised serum sodium concentrations. ${ }^{12-16}$

I would rather argue that a fundamental feature of all prospective trials that aim to evaluate a novel intervention such as the role of sodium ingestion in the prevention of hyponatraemia during exercise should be to compare the new intervention with the currently established "best practice".

As the currently established best practice is not to ingest fluid at such high rates that weight is gained during exercise, because this practice can produce a fatal outcome, ${ }^{17}$ so this study design should, in retrospect, not have been sanctioned. Rather, the control group in the study should have ingested fluid according to guidelines based on the strongest body of current information. It is, for obvious reasons, my biased opinion that the guidelines that come closest to a defendable evidence base are those that have been recently accepted by the United States Track and Field and the International Marathon Medical Directors Association. ${ }^{16}$

Fortunately the data of Twerenbold et al ${ }^{1}$ do allow some calculations to estimate the likely value of the extra sodium that was ingested by two of their groups. Thus, the athletes in their study had a mean weight of $58 \mathrm{~kg}$. According to the formula of Montain et al, ${ }^{18}$ their predicted extracellular fluid (ECF) volume would be about 14.5 litres $(25 \%$ of body weight). As the starting serum (and ECF) sodium concentration $\left(\left[\mathrm{Na}^{+}\right]\right)$in the three groups of runners was $\sim 137 \mathrm{mmol} / \mathrm{l}$ (table 3 of their article ${ }^{1}$ ), the average total ECF $\mathrm{Na}^{+}$content of the three experimental groups was 1989-1993 mmol at the start of the race. As weights increased by $1.8-2.1 \mathrm{~kg}$ in the three groups during exercise (table 3 of their article ${ }^{1}$ ), the increases in ECF volume would have been $450-525 \mathrm{ml}$ in the respective groups, assuming that the ECF increased in proportion to the increase in total body water (TBW). Multiplying this new ECF volume by the serum $\left[\mathrm{Na}^{+}\right]$after the race gives the new total ECF $\mathrm{Na}^{+}$content after the race. As shown in table 1 , the total ECF $\mathrm{Na}^{+}$ content increased by $34 \mathrm{mmol}$ in the group that ingested the high salt drink $(\mathrm{H})$ during the race, but fell by $23 \mathrm{mmol}$ in the group drinking water (W). As all groups ran for about four hours, according to these calculations and based on these assumptions, the hourly rates of $\mathrm{Na}^{+}$loss would have varied from 6 to $21 \mathrm{mmol} / \mathrm{h}$, giving a sweat $\left[\mathrm{Na}^{+}\right]$of $12-42 \mathrm{mmol} / \mathrm{l}$ in the $\mathrm{W}$ and $\mathrm{H}$ groups respectively (as their total sweat losses were $\sim 2$ litres in each group).

The clear paradox identified by the calculations in table 1 is that $(a)$ the total $\mathrm{Na}^{+}$loss apparently increases with increased $\mathrm{Na}^{+}$ intake and $(b)$ the estimated $\mathrm{Na}^{+}$loss in the group who ingested only water during the race $(\mathrm{W})$ is less than one third of that in the group who ingested the most $\mathrm{Na}^{+}(\mathrm{H})$ during the race.

As these calculations are based on two real measurements (body weight changes and changes in plasma $\left.\left[\mathrm{Na}^{+}\right]\right)$, this apparently ludicrous conclusion can only be explained if (a) $\mathrm{Na}^{+}$ingestion during exercise increases whole body $\mathrm{Na}^{+}$losses in sweat and urine or (b) the estimated ECF volume in the W group after exercise is less than the value calculated. That is, specifically in the $\mathrm{W}$ group, the ECF volume contracted despite an increase in TBW of 1.9 litres. Indeed, this response is to be expected. There is consistent evidence that the response of the ECF and the intracellular fluid (ICF) volumes to fluid ingestion during prolonged exercise are influenced by the $\mathrm{Na}^{+}$ content of the ingested fluid ${ }^{19-21}$ so that the plasma volume is likely to fall the most if no fluid is ingested, ${ }^{19}$ to fall less if either water ${ }^{19}$ or a dilute $\mathrm{Na}^{+}$drink is ingested, ${ }^{19-21}$ or to expand if a concentrated (50-100 mmol/l) $\mathrm{Na}^{+}$drink is ingested at the same rate that body weight is lost during exercise. ${ }^{20}$ In the latter case, any reduction in the TBW appears to come from a reduction in the ICF. ${ }^{20}$

For example, if each group did indeed lose $84 \mathrm{mmol} \mathrm{Na}^{+}$as did group $\mathrm{H}$ (table $\mathrm{l}$ ), a value that seems eminently reasonable as it equates to a quite reasonable sweat $\left[\mathrm{Na}^{+}\right]$of $\sim 40 \mathrm{mmol} / \mathrm{l},{ }^{22}$ then the true ECF volume in the $\mathrm{W}$ group after the race would have been 14.5 litres-that is, it is unchanged from the starting value. This value (expressed in litres) is calculated as: (pre-race ECF $\mathrm{Na}^{+}$content 84 ) in mmol divided by post-race serum $\left[\mathrm{Na}^{+}\right]$in $\mathrm{mmol} / \mathrm{l}$.

Indeed, if subjects in the $\mathrm{W}$ group did lose $84 \mathrm{mmol} \mathrm{Na}^{+}$during the race but also had a post-race ECF volume expanded to 14.95 litres, then their post-race $\left[\mathrm{Na}^{+}\right]$would have been even lower $(128 \mathrm{mmol} / \mathrm{l})$ than that actually measured after the race $(132 \mathrm{mmol} / \mathrm{l}$; table 1). It is probable that, at that low serum $\left[\mathrm{Na}^{+}\right]$, they would have exhibited the early symptoms of hyponatraemic encephalopathy. ${ }^{11}$ That they did not have such low serum $\left[\mathrm{Na}^{+}\right]$indicates the importance of small changes in ECF volume (in this case only $450 \mathrm{ml}$ or $\sim 3 \%$ of the total ECF volume) in determining the extent to which the serum $\left[\mathrm{Na}^{+}\right]$changes during prolonged exercise in which subjects both sweat and ingest fluid to excess. ${ }^{11}$

Unfortunately, the vital importance of these small changes in ECF volume in determining whether hyponatraemic encephalopathy will develop in those who overdrink during exercise ${ }^{11}$ continues fastidiously to be ignored by those $e^{1-61823-25}$ who argue incorrectly that it is the $\mathrm{Na}^{+}$deficit that determines the extent to which the serum $\left[\mathrm{Na}^{+}\right]$ falls in those who develop hyponatraemia during exercise. This calculation elegantly shows why small changes in ECF volume determine whether or not hyponatraemic 
Table 1 Sodium balance calculations for three groups of runners running at $\sim 10 \mathrm{~km} / \mathrm{h}$ for four hours while ingesting solutions with different $\left[\mathrm{Na}^{+}\right]$

\begin{tabular}{|c|c|c|c|c|c|c|c|c|c|}
\hline & $\begin{array}{l}\text { Pre-race } \\
{\left[\mathrm{Na}^{+}\right]} \\
(\mathrm{mmol} / \mathrm{I})(\mathrm{A})\end{array}$ & $\begin{array}{l}\text { Pre-race } \\
\text { ECF volume } \\
\text { (litres) (B) }\end{array}$ & $\begin{array}{l}\text { Pre-race ECF } \\
\mathrm{Na}^{+} \text {content } \\
(\mathrm{mmol})(\mathrm{A} \times \mathrm{B})\end{array}$ & $\begin{array}{l}\text { Post-race }\left[\mathrm{Na}^{+}\right] \\
(\mathrm{mmol} / \mathrm{ll})(\mathrm{C})\end{array}$ & $\begin{array}{l}\text { Post-race } \\
\text { ECF volume } \\
\text { (litres) (D) }\end{array}$ & $\begin{array}{l}\text { Post-race ECF } \\
\mathrm{Na}^{+} \text {content } \\
(\mathrm{mmol})(\mathrm{C} \times \mathrm{D})\end{array}$ & $\begin{array}{l}\text { Post-race } \mathrm{Na}^{+} \\
\text {balance }(\mathrm{mmol})(\mathrm{E}) \\
(\mathrm{C} \times \mathrm{D})-(\mathrm{A} \times \mathrm{B})\end{array}$ & $\begin{array}{l}\text { Amount of } \\
\mathrm{Na}^{+} \text {ingested } \\
\text { (mmol) (F) }\end{array}$ & $\begin{array}{l}\text { Apparent amount } \\
(\mathrm{mmol}) / \text { rate } \\
\text { of } \mathrm{Na}^{+} \text {loss during } \\
\text { exercise (mmol/h) } \\
((\mathrm{F}-\mathrm{E}) / 4)\end{array}$ \\
\hline $\mathrm{H}$ & 137.3 & $14.50^{*}$ & 1991 & 134.8 & 15.02 & 2025 & +34 & $118 \dagger$ & $84 / 21$ \\
\hline L & 137.2 & 14.50 & 1989 & 132.8 & 14.95 & 1985 & -4 & 71 & $76 / 19$ \\
\hline W & 137.5 & 14.50 & 1993 & 131.8 & 14.95 & 1970 & -23 & 0 & $24 / 6$ \\
\hline
\end{tabular}

$\mathrm{H}$, High sodium intake; $\mathrm{L}$, low sodium intake; $\mathrm{W}$, water during exercise.

*Based on $25 \%$ of mean body weight of $57.7 \mathrm{~kg}$ for the total group of runners. Weights for different groups were not reported.

†From table 2 of Twerenbold et al': to convert $\mathrm{mg}$ sodium (table 2) into mmol sodium, divide by the molecular weight of sodium (22.99).

encephalopathy will develop in those who overdrink, regardless of whether or not they also incur a $\mathrm{Na}^{+}$deficit either during exercise $^{311-13152627}$ or at rest. ${ }^{229}$ A recent paper ${ }^{30}$ confirms these predictions by showing that mathematical modelling supports the argument that changes in TBW exert a much greater effect on serum $\left[\mathrm{Na}^{+}\right]$than does whole body $\mathrm{Na}^{+}$content in those who overdrink and hence gain weight during exercise.

Perhaps the point of these calculations is to show that it is not possible to calculate the state of $\mathrm{Na}^{+}$balance in athletes during exercise and so to determine whether or not athletes have developed a $\mathrm{Na}^{+}$"deficit", ${ }^{1623-25}$ simply by measuring serum $\left[\mathrm{Na}^{+}\right]$. This is because the ECF volume will not be the same before, during, and after exercise and will change depending on the nature of the fluid ingested and the extent of any fluid deficit or excess that develops during exercise..$^{19-21}$

But more importantly, these calculations clearly show why the regulation of the TBW and the ECF volume will have a much greater influence on serum $\left[\mathrm{Na}^{+}\right]$than will either the expected $\mathrm{Na}^{+}$losses in sweat or the amount of $\mathrm{Na}^{+}$ingested from sodium-containing sports drinks. ${ }^{11}{ }^{30}$

For example a 1 litre $(7 \%)$ reduction in the ECF volume would "release" $140 \mathrm{mmol} \mathrm{Na}{ }^{+}$ into the contracted ECF volume. This means that it is possible to lose $140 \mathrm{mmol} \mathrm{Na}{ }^{+}$in sweat and urine without any change in serum $\left[\mathrm{Na}^{+}\right]$provided that the ECF volume were to contract by only $7 \%$. If sweat $\left[\mathrm{Na}^{+}\right]$is about $40 \mathrm{mmol} / \mathrm{l}$, as appears to have been the case in this study of Twerenbold et al (table 1), then this $140 \mathrm{mmol}$ is the equivalent of the $\mathrm{Na}^{+}$content of about 3.5 litres of sweat.

As athletes in this study sweated at a maximum rate of only $500 \mathrm{ml} / \mathrm{h}$ when running at $10 \mathrm{~km} / \mathrm{h}$, this means that simply by reducing their ECF volume by 1 litre, those athletes could have maintained their pre-race serum $\left[\mathrm{Na}^{+}\right]$while running for seven hours and drinking just sufficient water to allow for a 1 litre reduction in ECF volume and without requiring any $\mathrm{Na}^{+}$replacement whatsoever. This simple calculation explains why those endurances athletes who, before about 1969, were advised either not to drink at all, or only sparingly during exercise, ${ }^{31}$ always finished their races with raised serum $\left[\mathrm{Na}^{+}\right]^{32-39}$ despite having incurred what might have been quite sizeable $\mathrm{Na}^{+}$deficits.

In contrast, athletes in this study who believed the incorrect advice that ingesting $\mathrm{Na}^{+}$and fluid at high rates is essential to maintain a normal serum $\left[\mathrm{Na}^{+}\right]$during exercise, ${ }^{4-61823-25}$ so they overdrank sufficiently to increase their ECF volume by
1 litre, would need to ingest and retain at least an additional $140 \mathrm{mmol} \mathrm{Na}^{+}$in addition to the $\sim 80 \mathrm{mmol}$ lost in sweat (table 1). This is equivalent to the $\mathrm{Na}^{+}$content of 12.4 litres of the low and 7.5 litres of the high sodium drinks respectively in this trial. To maintain fluid balance in this four hour trial when drinking at those high rates and sweating at about $500 \mathrm{ml} / \mathrm{h}$, they would then need to urinate at rates of $1375-2600 \mathrm{ml} / \mathrm{h}$. Both of these rates exceed the maximum at which human kidneys are able to produce urine at rest, ${ }^{28} 29$ let alone during and after prolonged exercise. ${ }^{11}{ }^{13}$ Drinking at such rates would therefore only lead to progressive fluid accumulation and ultimately death from hyponatraemic encephalopathy. ${ }^{17}$

In summary, these calculations explain (a) why contraction of the ECF in athletes who lose body weight during exercise will maintain the serum $\left[\mathrm{Na}^{+}\right]$even in the face of quite large and unreplaced $\mathrm{Na}^{+}$loss in sweat, and (b) why the ingestion of sodium-containing sports drinks in the vain hope of matching the rates of $\mathrm{Na}^{+}$loss in sweat can only lead to fluid retention and progressive hyponatraemia, as elegantly shown by this study.' Indeed if this inappropriate behaviour is approached with sufficient vigour, ultimately the result will be death from hyponatraemic encephalopathy, ${ }^{17}$ which, as these calculations and this study again show, cannot occur without the presence of distinct fluid overload. ${ }^{11}$

Finally, it is important to note that, even though $\mathrm{Na}^{+}$ingestion marginally increased serum $\left[\mathrm{Na}^{+}\right]$in the group that ingested the most concentrated $\mathrm{Na}^{+}$drink, this practice was without benefit as running performances were unaltered by $\mathrm{Na}^{+}$ingestion, and the incidence of symptoms was no different between the groups as no athletes reportedly developed symptoms. However, the symptoms of mild hyponatraemic encephalopathy are mild and may not have been sought with sufficient diligence. For example, all subjects, myself included, in our study in which mild hyponatraemia was induced by fluid overload at rest, ${ }^{28}$ developed quite disabling symptoms at serum $\left[\mathrm{Na}^{+}\right]$of $\sim 136 \mathrm{mmol} / \mathrm{l}$ or lower. Indeed it would have been most interesting to determine whether the presence of subtle mental symptoms was different in the three groups in this study, as all had similar degrees of fluid overload despite different serum $\left[\mathrm{Na}^{+}\right]$. If the symptoms in this condition are due purely to fluid overload, then the incidence of symptoms should have been the same in all groups despite different serum $\left[\mathrm{Na}^{+}\right]$. Alternatively, if the symptoms are related to the degree of hyponatraemia, then they should have been most obvious in the $\mathrm{W}$ group, who finished with the lowest postrace serum $\left[\mathrm{Na}^{+}\right]$. My bias would be to expect that the extent of any symptoms are more likely related to the degree of fluid overload, and hence the increase in the ICF, than to the level to which the serum $\left[\mathrm{Na}^{+}\right]$has been reduced.

T Noakes

Correspondence to: University of Cape Town, Research Unit for Exercise Science and Sports Medicine, Sports Science of South Africa, PO Box

115, Newlands 7725, South Africa; tdnoakes@ sports.uct.ac.za

doi: 10.1136/bjsm.2004.014191

Conflict of interest: none declared

\section{References}

1 Twerenbold R, Knechtle B, Kakebeeke TH, et al. Effects of different sodium concentrations in replacement fluids during prolonged exercise in women. Br J Sports Med 2003;37:300-3

2 Pastene J, Germain M, Allevard AM, et al. Water balance during and after marathon running. Eur J Appl Physiol Occup Physiol 1996;73:49-55

3 Speedy DB, Noakes TD, Kimber NE, et al. Fluid balance during and after an ironman triathlon. Clin J Sport Med 2001;11:44-50.

4 Convertino VA, Armstrong LE, Coyle EF, et al. American College of Sports Medicine position stand. Exercise and fluid replacement. Med Sci Sports Exerc 1996;28:i-vii.

5 Armstrong LE, Epstein YE, Greenleaf JE, et al. Position stand: heat and cold illnesses during distance running. Med Sci Sports Exerc 1996;28:i-x

6 Murray B. How often should you drink fluids? Gatorade Sports Science Institute Sports Science Centre. 2002. http://www.gssiweb.com/reflib/ refs/419/200104_q1.cfm?pid = 38 .

7 Robinson TA, Hawley JA, Palmer GS, et al. Water ingestion does not improve 1-h cycling performance in moderate ambient temperatures Eur J Appl Physiol Occup Physiol 1995;71:153-60.

8 Noakes TD. Letter to the Editor. Int J Sport Nutr Exerc Metab 2004; 14:249-54.

9 Glace B, Murphy C, McHugh M. Food and fluid intake and disturbances in gastrointestinal and mental function during an ultramarathon. Int J Sport Nutr Exerc Metab 2002:12:414-27.

10 Glace BW, Murphy CA, McHugh MP. Food intake and electrolyte status of ultramarathoners competing in extreme heat. $J \mathrm{Am}$ Coll Nutr 2002;21:553-9.

11 Noakes T. Hyponatremia in distance runners: fluid and sodium balance during exercise. Curr Sports Med Rep 2002;1:197-207.

12 Speedy DB, Noakes TD, Rogers IR, et al. Hyponatremia in ultradistance triathletes. Med Sci Sports Exerc 1999:31:809-15.

13 Noakes TD, Sharwood K, Collins M, et al. The dipsomania of great distance. Water intoxication 
in an Ironman triathlete $\mathrm{Br} J$ Sports Med 2004;38:el6.

14 Sharwood K, Collins M, Goedecke J, et al. Weight changes, medical complications and performance during an Ironman triathlon. Br J Sports Med 2004; in press.

15 Speedy DB, Rogers IR, Noakes TD, et al. Diagnosis and prevention of hyponatremia at an ultradistance triathlon. Clin J Sport Med $2000 \cdot 10 \cdot 52-8$

16 Noakes TD. Fluid Replacement during Marathon Running. Clin J Sport Med 2003;13:309-18.

17 Noakes TD. Overconsumption of fluids by athletes. BMJ 2003;327:113-14.

18 Montain SJ, Sawka MN, Wenger CB. Hyponatremia associated with exercise: risk factors and pathogenesis. Exerc Sport Sci Rev 2001;29:113-17.

19 Sanders B, Noakes TD, Dennis SC. Water and electrolyte shifts with partial fluid replacement during exercise. Eur $J$ Appl Physiol Occup Physiol 1999;80:318-23.

20 Sanders B, Noakes TD, Dennis SC. Sodium replacement and fluid shifts during prolonged exercise in humans. Eur J Appl Physiol 2001;84:419-25.

21 Speedy DB, Thompson JM, Rodgers I, et al. Oral salt supplementation during ultradistance exercise. Clin J Sport Med 2002;12:279-84

22 Shirreffs SM, Maughan RJ. Whole body sweat collection in humans: an improved method with preliminary data on electrolyte content. $J$ Appl Physiol 1997:82:336-41.

23 Armstrong LE. Exertional hyponatremia. In: Armstrong LE, ed. Exertional heat illnesses. Champaign, IL: Human Kinetics Publishers, 2003:103-35.

24 Murray B, Eichner ER. Hyponatremia of exercise. Curr Sports Med Rep 2004;3:117-18.

25 Murray B, Stofan J, Eichner ER. "Water intoxication" and subsequent death has become a "hot" topic. How dangerous is it? Marathon \& Beyond 2004 Jan/Feb:77-92.

26 Irving RA, Noakes TD, Buck R, et al. Evaluation of renal function and fluid homeostasis during recovery from exercise-induced hyponatremia. J Appl Physiol 1991;70:342-8.

27 Speedy DB, Rogers IR, Noakes TD, et al. Exercise-induced hyponatremia is caused by inappropriate fluid retention. Clin J Sport Med 2000;10:272-8.

28 Noakes TD, Wilson G, Gray DA, et al. Peak rates of diuresis in healthy humans during oral fluid overload. S Afr Med J 2001;91:852-7.

29 Speedy DB, Noakes TD, Boswell T, et al Response to a fluid load in athletes with a history of exercise induced hyponatremia. Med Sci Sports Exerc 2001;33:1434-42.

30 Weschler LB. Exercise-associated hyponatremia: sensitivity of plasma $\mathrm{Na}^{+}$concentration to total body water, change in total body water and sum of exchangeable $\mathrm{Na}^{+}$and $\mathrm{K}^{+}$. Sports Med 2004; in press.

31 Noakes TD. Fluid replacement during exercise Exerc Sport Sci Rev 1993;21:297-330.

32 Beckner GL, Winsor T. Cardiovascular adaptations to prolonged effort. Circulation 1954;9:835-46

33 Pugh LGCE, Corbett JL, Johnson RH. Rectal temperatures, weight losses, and sweat rates in marathon running. J Appl Physio 1967;23:347-52.

34 Muir AL, Percy-Robb IW, Davidson IA, et al. Physiological aspects of the Edinburgh Commonwealth Games. Lancet 1970;2:1125-8.

35 Rose LI, Carroll DR, Lowe SL, et al. Serum electrolyte changes after marathon running. J Appl Physiol 1970;29:449-51.

36 Kavanagh T, Shephard RJ. Marathon running after myocardial infarction. JAMA 1974;229:1602-5.

37 Riley WJ, Pyke FS, Roberts AD, et al. The effects of long-distance running on some biochemical variables. Clin Chim Acta 1975;65:83-9

38 Noakes TD, Carter JW. Biochemical parameters in athletes before and after having run $160 \mathrm{~km}$. S Afr Med J 1976;50:1562-6.

39 McKechnie JK, Leary WP, Noakes TD. Metabolic responses to a $90 \mathrm{~km}$ running race. S Afr Med J 1982;61:482-4.

\section{BOOK REVIEWS}

\section{Tennis}

Edited by P A F H Renstrom. London: Blackwell Publishing, 2002, £29.95, pp 318, softcover. ISBN 0632050349

It is widely recognised that each sport has its own unique demands and injuries. Therefore the IOC, ITF, ATP, WTA, and Society for Tennis Medicine and Science should be congratulated on producing, in this publication, a comprehensive overview of tennis sports medicine. Together they have assembled an impressive array of experts in this field to write succinct and relevant chapters.

Every aspect of tennis is covered to cater for a broad range of readers, including players themselves. Some areas are covered in a high level of technical detail to please the biomechanists, in particular. However, some of the sports medicine is basic in concept and lacking significant evidence based validity.

Nevertheless, I would highly recommend this book to any health professional who treats a large number of tennis players. Most chapters provide a clever link between common sports medicine problems and their occurrence in tennis, including conditions that are unique to this sport. At times, some authors are somewhat optimistic with their view of recovery time from surgery-for example, three weeks for arthroscopic debridement of the infrapatellar fat pad.

Overall it is well presented with relevant and useful photographs and diagrams to aid the reader, and each chapter gives a list of further recommended reading. Unfortunately the book does not provide an answer to where 14 million tennis balls go, imported each year into Australia, as discussed by the editor recently!

\section{Rating}

- Presentation

- Comprehensiveness

- Readability

- Relevance

- Evidence basis

- Total $16 / 20$

$15 / 20$

$15 / 20$

$16 / 20$

$13 / 20$

$75 / 100$
T Wood

\section{Dying to win}

Edited by B Houlihan. Council of Europe Publishing, 2002, £17.95, softcover, pp 247. ISBN 9287146853

Dying to win gives an eye opening account of the extent to which drugs play a major role in sport. Doping is not new and has been used in sport since ancient Olympic times; it is just that drug use in modern times is at such a level of sophistication, it is now an industry in its own right. The book describes the privileged position sport holds in society, having appeal for both the participant and the spectator. This has led to the massive media interest, commercialism, professionalism, and governmental regulation and manipulation. Economic pressure in the industrialised world and governmental propaganda in the former East Germany, and more recently China, paved the way for the increasing pharmaceutical intervention in sport. With the fall of the GDR, the world saw for the first time what it had long suspected, the extent of systematic doping on a State run basis, and the most interesting fact is that the East Germans kept excellent records! Further, the book takes a look at the next big issue surrounding drugs in sportgenetic engineering.

Dying to win does not just describe the evolution of doping. It explains the complex relation between anti-doping policy, implementation of those policies, and the role of governments, the IOC, and international and national sporting organisations. With the ever increasing involvement of the legal profession, a vicious circle occurs: it becomes too costly for sporting organisations to fight court battles, with their reliance on Government funding depending on results and punishments set in accordance with what will stand up in courts. This all leads to the relative inertia of the governing bodies to be pro-active in the anti-drugs campaign. The inception of the World Anti-Doping Agency (WADA) after the 1998 Tour de France drugs fiasco provided a way forward to standardise and implement anti-doping policy across the world by an independent body.

Problems and solutions to anti-doping policy are addressed. The major problem is inadequate definition of doping - to quote Arthur Gold "The definition lies not in words but in integrity of character.". It is interesting to note that those behind the athlete, namely coach, administrators, medical profession, and scientists, all seem to lose perspective along with their ethics and "integrity of character" when the race for "gold" is on. Dying to win suggests that these people should be held just as accountable as the athletes themselves. Another unfortunate aspect of anti-doping policy is the difficulty in detecting some abused drugs and the fact that these strategies often lag way behind the ability of the pharmaceutical industry to develop new drugs, often for genuine medical reasons but with the unfortunate ability to enhance performance. Education is proposed as a key aspect to anti-doping policy, and parallels with its success in the use of recreational drugs are made. Governments also play a role in limiting supply, decreasing demand for drugs, and the implementation of independent bodies to carry out drug testing. The success of anti-doping policy is also hard to measure. Fewer positive tests may simply reflect a move to less detectable methods rather than a decrease in use, and success may be better measured in terms of fewer world records.

Dying to win gives an accurate account of the problem of doping in sport and the difficulties and complexities in finding solutions to the problems. It makes interesting and provocative reading for all those involved in sport, from the athlete and coach to the sport administrator, the medical profession, and governments. 


\section{Rating}

- Presentation

- Comprehensiveness

- Readability

- Relevance

- Evidence basis

- Total

$17 / 20$

$19 / 20$

$15 / 20$

$18 / 20$

$19 / 20$

$88 / 100$

E Clisby

Chair Drugs in Sport, Sports Medicine Australia; eclisby@healthon-net.com

\section{CALENDAR OF EVENTS}

\section{UK Radiological Congress 2005 (UKRC 2005)}

6-8 June 2005, Manchester, UK

The UK Radiological Congress (UKRC) meeting will encompass the medical, scientific, educational, and management issues that are of interest and relevance to all those involved in the diverse fields of radiological sciences and oncology.

The UKRC provides a forum in which to bring together clinicians, scientists, radiographers, technicians, and other professionals to present and discuss the latest developments and challenges in diagnostic imaging, radiotherapy, and allied radiological sciences.

Key subjects to be covered include: diagnostic radiology; ultrasound; nuclear medicine; interventional radiology; veterinary radiology; emerging technologies; image analysis; computer applications; PACS; radiobiology; radiological physics; management \& audit; computed tomography; magnetic resonance; equipment development.

Expected attendance (conference and exhibition): 4000

Further details: UKRC 2005 Organisers, PO Box 2895, London WIA 5RS, UK; Website: www.ukrc.org.uk; Fax: +44 (0)20 7307 1414; Conference tel: +44 (0)20 7307 1410, Email: conference@ukrc.org.uk; Exhibition tel: +44 (0)207307 1420, Email: exhibition@ukrc. org.uk

\section{1st World Congress on Sports Injury} Prevention

23-25 June 2005, Oslo, Norway

This congress will provide the world's leading sports medicine experts with an opportunity to present their work to an international audience made up of physicians, therapists, scientists, and coaches. The congress will present scientific information on sports injury epidemiology, risk factors, injury mechanisms and injury prevention methods with a multidisciplinary perspective. Panel discussions will conclude symposia in key areas providing recommendations to address the prevention issue in relation to particular injuries and sports.

Further details: Oslo Sports Trauma Research Centre and Department of Sports Medicine, University of Sport and Physical Education, Sognsveien 220, 0806 Oslo, Norway. Email: 2005congress@nih.no; website: www.ostrc.no

\section{Osteosynthese International 2005}

15-17 September 2005, Curiohaus, Hamburg Congress-Chairman: Johannes M. Rueger,

M.D., Professor and Chair Topics:

- Innovations in intramedullary osteosynthesis

- New frontiers in osteoporosis and fracture treatment

- Current trauma research

- Special topic: Recent development in pelvic and acetabular fractures

Abstract submission deadline: 31 March 2005

Further details: INTERCONGRESS GmbH, Martin Berndt, Düsseldorfer Str. 101, 40545 Düsseldorf-Germany. Tel: +49 $211585897-$ 80; fax: +49 211 585897-99; email: martin. berndt@intercongress.de; website: www. osteoint2005.de

\section{4th European Sports Medicine Congress}

13-15 October 2005, Lemesos, Cyprus

Further details: Email: pyrgos.com@cytanet. com.cy

\section{BASEM Conference 2005}

10-12 November 2005, Edinburgh, Scotland Further details: Email: basemoffice@ compuserve.com
BASEM Conference 2006

5-7 October 2006, Oxford, UK

Further details: Email: basemoffice $a$ compuserve.com

\section{CORRECTIONS}

doi: 10.1136/bjsm.2004.00392 1corr l

Cicharro J L, Hoyos J, Gómez-Gallego F, et al. Mutations in the hereditary haemochromatosis gene HFE in professional endurance athletes (Br J Sports Med 2004;38:418-21). The affiliation of $\mathrm{P}$ Celaya was published incorrectly. The correct affiliation is Professional Cycling Team US Postal-Berry Floor. We apologise for this error.

doi: 10.1136/bjsm.2004.000044corr 1

Dadebo B, White J, George K P. A survey of flexibility training protocols and hamstring strains in professional football clubs in England (Br J Sports Med 2004;38:388-94). The multiple regression equation within the Abstract section of this paper was published incorrectly. The correct equation is:

$\mathrm{HSR}=37.79-(0.33 \mathrm{SHT}+10.05 \mathrm{SSP}+2.24 \mathrm{STE})$ $\pm 2.34$

We apologise for this error.

doi: 10.1136/bjsm.2004.010876corr l

Sran M M. To treat or not to treat: new evidence for the effectiveness of manual therapy (Br J Sports Med 2004;38:521-5).

The volume number for reference 23 (Sran et al) was incorrectly published as 24; the correct volume number is 29 .

In Table 2 the results for Giles and Muller should read: Greater short term benefit for back pain with manipulation, but not for neck pain. Acupuncture more effective for neck pain.

In the section "Definitions and search strategy" the first line of paragraph 2 should read: I searched Medline, Cinahl, and Embase databases for randomised clinical trials comparing manual therapy, including spinal joint mobilisation (with or without manipulation) or manipulation only with other conservative treatments for back or neck pain.

We apologise for these errors. 